\title{
PENGARUH METODE PEMBELAJARAN DEMONSTRASI BERBANTUAN SOFTWARE GEOGEBRA TERHADAP PEMAHAMAN MATEMATIKA SISWA PADA POKOK BAHASAN TRANSFORMASI GEOMETRI
}

\author{
Lilis Rodiawati, S.Pd \\ MAN 2 Kota Cirebon \\ J1. Bandung A2 No, 1 Taman Nuansa Majasem \\ lilisrosdiawati@gmail.com
}

\begin{abstract}
Abstrak
Penelitian ini bertujuan untuk mengetahui pengaruh pembelajaran metode demonstrasi berbantuan software geogebra terhadap pemahaman matematika siswa. Penelitian ini menggunakan metode penelitian eksperimen dengan desai penelitian one short case study. Teknik pengumpulan data menggunakan instrumen tes matematika dan angket respon metode demonstrasi. Populasi penelitian ini adalah semua kelas X dengan kelas XA sebagai sampel berjumlah 40 siswa. Hasil penelitian menunjukkan rata-rata pemahaman matematika siswa adalah 35. Hasil respon siswa terhadap metode demonstrasi berbantuan geogebra sebesar $85 \%$ respon positif. Dan terdapat pengaruh antar penggunaan metode demonstrasi berbantuan software geogebra terhadap pemahaman matematika siswa.
\end{abstract}

Kata Kunci: metode demonstrasi, geogebra, matematika

\section{Abstract}

This research aim to to analyze the influence of study method demonstrate by software geogebra to understanding of student mathematics. Research method used in this research is experimen by desain is research of One Short Chase Study. To get the research data used by instrument of tes essay of mathematics and response enquette to method demonstrate the. this Research population is alk student class $X$, with the class $A$ as sampel research amount to 40 student. Result of research indicate that the mean assess the understanding of student mathematics of equal to 35. analysis of Data of enquette of respon student to study method demonstrate by software geogebra show $85 \%$ giving positive response. And test the influence show the happening of influence of applying of study method demonstrate by software geogebra to understanding of student mathematics.

Keyword: method demonstrate, geogebra, mathematics 


\section{A. PENDAHULUAN}

Dunia pendidikan telah mengalami perkembangan yang begitu pesat sesuai dengan kemajuan zaman saat ini. Situasi ini dibuktikan dengan adanya berbagai metode pembelajaran yang digunakan dalam proses pengajaran di sekolah. Sejalan dengan kondisi tersebut Ruseffendi (2006 : 260) berpendapat bahwa pendidikan adalah suatu tindakan membantu manusia untuk dapat mengembangkan potensinya sehingga mampu menghadapi permasalahan perkembangan zaman dengan sikap kreatif.

Untuk mengembangkan potensi yang dimiliki oleh siswa maka yang harus dilalui adalah dengan proses belajar. Belajar sebagai jembatan untuk memperoleh pengetahuan dan keterampilan siswa demi meningkatkan kemampuan pemahaman dan berpikir agar tetap bisa bersaing pada zamannya. Siswa hendaknya mengoptimalkan proses belajar ini dengan cara memperhatikan penjelasan guru saat di kelas dan membaca sumber referensi lainnya.

Belajar adalah proses perubahan perilaku atas hasil pengalaman dalam berinteraksi terhadap lingkungan (Rusman, 2011 : 134). Dalam proses belajar siswa menunjukkan aktivitas berpikir dan menganalisis materi yang disampaikan. Hasil belajar siswa ditandai dengan perubahan tingkah laku dan kemampuan berpikir. Belajar adalah memodifikasi atau memperteguh perilaku melalui pengalaman. Belajar ialah proses atau kegiatan yang tidak menuntut hasil namun belajar adalah proses mengalami (Hamalik, 2009 : 36). Sehingga belajar dapat diartikan suatu proses yang dialami secara sadar demi perubahan tingkah laku yang baru terkait dengan kognitif, afektif dan psikomotor siswa sebagai hasil interaksi atau pengalaman yang telah dialaminya.

Seorang guru yang aktif dan tanggap memilih metode pembelajaran akan mendorong siswa ke arah perubahan kemampuan berpikir kritis dan kreatif. Pemilihan dan pengembangan metode pembelajaran diperlukan pada setiap memasuki topik bahasan baru. Fakta di lapangan ditemukan bahwa masih banyak guru yang hanya memakai metode ceramah dalam penyampaian materi pelajaran matematika di kelas. Sehingga suasana menjadi jenuh dan memberikan efek kepada siswa kurangnya pemahaman karena hanya mendengarkan kemudian mengerjakan tugas latihan soal.

Metode pembelajaran yang tepat dan aktif memberikan dampak yang positif kepada siswa untuk ikut berpartisipasi dan menumbuhkan minat belajar matematika. Interaksi dalam pembelajaran matematika masih dianggap kurang karena siswa masih lebih banyak duduk dan mendengarkan penjelasan guru. Pembelajaran matematika bukan sekedar mengerti yang disampaikan oleh guru, namun pembelajaran matematika siswa harus dapat mempresentasikan kembali teori dan 
mampu menghubungkan ke benda nyata / kehidupan sehari-hari.

Seiring perkembangan zaman yang kini terjadi tidak menutup kemungkinan adanya pengembangan metode pembelajaran yang dirancang oleh guru. Salah satu ciri perkembangan zaman adalah penggunaan produk teknologi yang disebut komputer. Komputer telah banyak digunakan sebagai alat bantu pembelajaran. Komputer dapat menggantikan suatu benda konkret yang dirubah ke dalam bentuk visual berdimensi tiga yang dapat diamati sejauh mungkin.

\section{B. KAJIAN TEORI}

Metode (Slameto, 2010 : 82) adalah suatu cara yang harus dilalui untuk mencapai tujuan tertentu. Metode juga dapat diartikan sebagai upaya menerapkan rencana secara nyata agar tercapainya tujuan yang direncanakan (Wina, 2008: 128). Berbagai faktor menjadi sebab pemilihan metode yang akan digunakan saat pembelajaran di kelas, diantara faktor adalah fasilitas mengajar di dalam ruang kelas, kelengkapan sarana di kelas sangat menunjang untuk pemilihan metode pembelajaran yang hendak digunakan. Kekurangan fasilitas ini dapat mengakibatkan terbatasnya pemilihan metode pembelajaran.

Metode demonstrasi adalah pembelajaran yang mempertunjukkan kepada siswa cara kerja / bentuk benda (Hamdani, 2011 : 269). Metode demonstrasi (Sanjaya. 2011 : 152) juga dapat diartikan sebagai sebuah penyajian pembelajaran dengan meragakan kepada siswa terhadap satu proses. Dengan adanya metode pembelajaran demonstrasi ini guru mempersiapkan suatu peragaan baik itu konkret dengan benda nyata atau dengan menggunakan media komputer untuk memberikan materi pelajaran kepada siswanya. Sehingga dapat dinyatakan bahwa metode demonstrasi meruapkan metode mengajar dengan memperagakan secara langsung proses terjadinya sesuatu sekaligus mengamati benda atau objek materi pelajaran disertai uraian secara lisan (Permana, 2011 : 17).

\section{Metode}

demonstrasi memberikan tanda penguasaan suatu kemampuan guru untuk memberikan pemahaman terkait teorema, rumus atau pemecahan soal matematika. Sehingga metode yang apabila dibiasakan ini maka dapat menciptakan siswa yang memiliki kemampuan pemahaman yang lebih baik pula. Adapun kelebihan metode pembelajaran demonstrasi menurut Sanjaya (2011 : 152) diantaranya:
a. Mengurangi terjadinya verbalisme, dikarenakan siswa memperhatikan bahan ajar atau peragaan yang dijelaskan oleh guru

b. Pembelajaran lebih menarik, sebab siswa bukan saja mendengarkan materi tetapi juga melihat suatu proses yang terjadi dengan adanya peragaan
c. Siswa memiliki kesempatan secara langsung untuk


membuktikan antara teori dan benda konkret sehingga siswa lebih yakin kebenaran suatu materi pelajaran

Metode demonstrasi secara garis besar dapat membantu siswa mengurangi keabstrakan dari materi pelajaran matematika. Sehingga pembelajaran matematika bagi siswa memiliki makna tersendiri yang bukan sekedar pelajaran namun memberikan pemahaman dalam kehidupan seharihari. Sedangkan kekurangan dari metode pembelajaran demonstrasi adalah:

a. Memerlukan persiapan yang matang, untuk mengurangi kegagalan selama proses berlangsung yang dapat mengakibatkan metode tidak efektif. Sehingga guru perlu melakukan percobaan

b. Memerlukan kemampuan dan keterampilan yang khusus juga kemauan dan motivasi yang besar untuk keberhasilan pembelajaran

Geogebra sebagai media demonstrasi matematika dirancang untuk mengamati geometri sekaligus aljabar secara simultan. Geogebra memiliki fitur-fitur visualisasi yang efektif dan interaktif kepada penggunanya untuk membuat berbagai konstruksi matematis. Sehingga proses pengamatan perubahan konstruksi dapat diteliti dengan mudah. Geogebra hadir sebagai software atau aplikasi matematika yang memungkinkan pengguna untuk terlibat langsung membuat objek matematika dengan memanipulasi objek matematika yang hendak disampaikan. Geogebra memberikan representasi objek matematika dalam geometri dan aljabar yang saling terhubung secara dinamis.

Pemahaman (Arikunto, 2009 : 118) adalah proses seseorang mempertahankan pengetahuan, membedakan, menduga, menerangkan, memperluas, menyimpulkan dan menulis kembali yang telah diperoleh. Dalam dunia pendidikan, pemahaman diartikan sebagai tujuan pembelajaran. Artinya bahwa dengan pemahaman siswa yang baik membuktikan bahwa materi atau konsep pembelajaran telah berhasil dilaksanakan. Menurut Ruseffendi (2006 : 221) pemahaman memiliki tiga kategori, diantaranya:

1. Pengubahan (penerjemah)

2. Pemberian arti (interpretasi)

3. Pembuatan (ekstrapolasi)

Pengubahan (penerjemahan) merupakan kemampuan untuk memahami ide atau gagasan yang dijelaskan kembali dengan cara yang berbeda namun tetap dengan makna yang sama. Pemberian arti (interpretasi) adalah kemampuan memahami konsep yang ditampilkan kembali melalui bentuk lain seperti grafik, tabel atau lainnya. Sedangkan pembuatan (ekstrapolasi) adalah kemampuan memperkirakan atau memprediksikan suatu kecenderungan yang mungkin ada menurut data atau informasi yang diperoleh, sebagai contoh mampu mengartikan suatu kesamaan. 
Menurut Pollastek dalam Sumarno pemahaman dikategorikan ke dalam dua jenis yaitu pemahaman komputasional dan pemahaman fungsional. Pemahaman komputasional adalah kemampuan menerapkan rumus dalam perhitungan yang sederhana dan mengerjakan perhitungan dengan algoritmik. Sedangkan pemahaman fungsional adalah kemampuan mengaitkan satu konsep dengan konsep lainnya. Sehingga dalam hal ini pemahaman memiliki arti yang luas dalam pembelajaran matematika, sehingga perlu dipertimbangkan metode yang akan digunakan dalam proses pembelajaran demi tercapainya tujuan pembelajaran yaitu pemamahan siswa terkait materi yang disampaikan.

Pemahaman matematika dapat diartikan bahwa suatu kemampuan yang harus dimiliki oleh siswa untuk dapat menjelaskan kembali konsep dasar matematika dan mampu mengembangkan konsep tertentu untuk memperoleh kesamaan atau perbedaan dengan konsep pengetahuan yang lain selain matematika itu sendiri. Pemahaman matematika adalah suatu proses pengamatan kognisi yang tak langsung dalam memperoleh informasi terkait konsep atau teori yang sedang dipahami. Sedangkan apabila ditinjau dari tujuan, pemahaman matematika berarti kemampuan memahami konsep, membedakan konsep-konsep dan kemampuan perhitungan secara bermakna pada situasi permasalahan yang lebih luas.

Indikator pemahaman matematika menurut NCTM meliputi :

1. Mendefinisikan konsep secara verbal dan tulisan

2. Mengidentifikasi dan membuat contoh

3. Menggunakan model, diagram dan simbol-simbol untuk mempresentasikan konsep

4. Mengubah suatu bentuk representatif ke bentuk lainnya

5. Mengenali berbagai makna dan interpretasi konsep

6. Mengidentifikasi sifat-sifat suatu konsep dan mengenal sarat yang menentukan konsep

7. Membanding dan membedakan konsep-konsep dan menerapkan konsep prosedur, prinsip dan ide matematika

Berbagai macam pilihan metode pembelajaran yang dapat digunakan untuk meningkatkan pemahaman matematika siswa. Salah satunya adalah metode pembelajaran demonstrasi yang dikembangkan melalui bantuan software geogebra. Metode pembelajaran demonstrasi merupakan bentuk penyajian pembelajaran dengan memperagakan materi secara visual secara langsung kepada siswa melalui media software geogebra yang disertai penjelasan lisan oleh guru. 


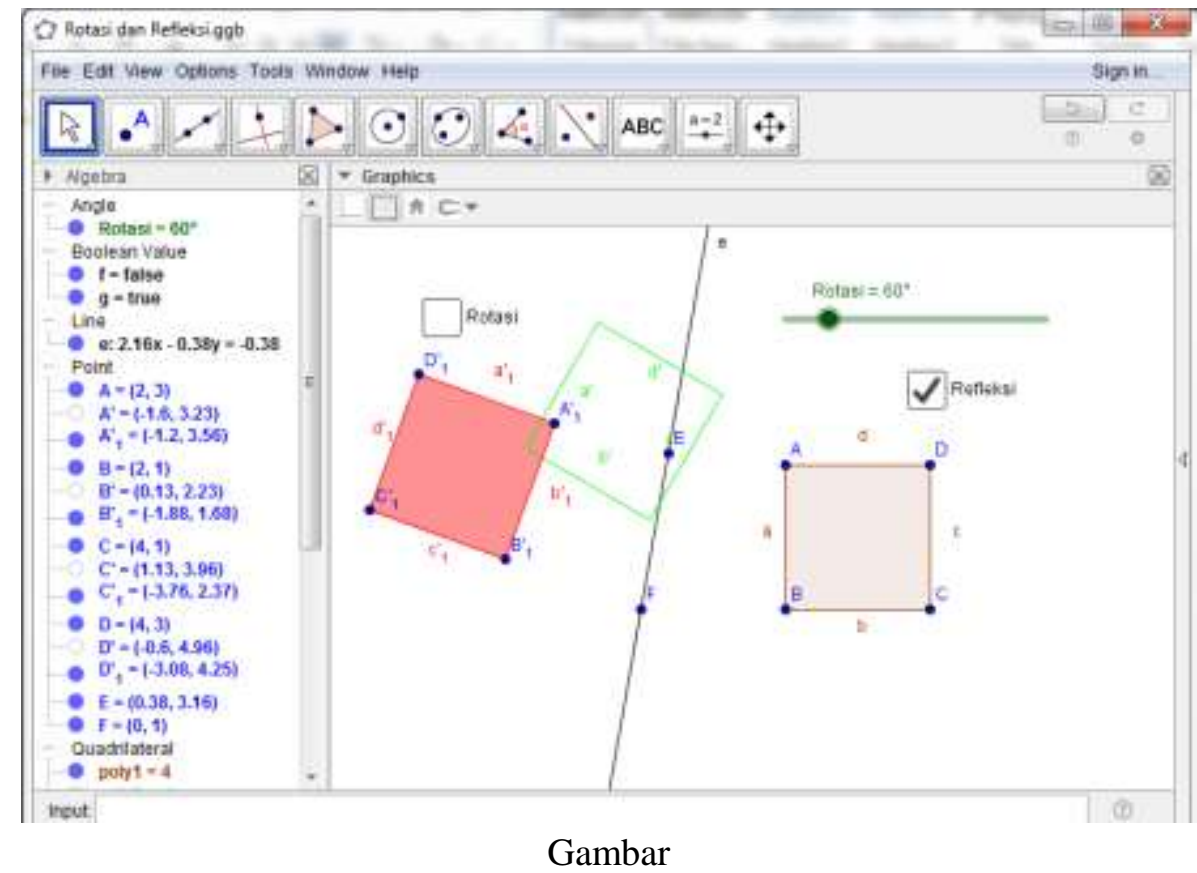

Konstruksi transformasi geometri dengan geogebra

\section{METODE PENELITIAN}

Penelitian ini dilaksanakan di MAN 2 kota Cirebon, sebagai variabel bebas adalah metode pembelajaran demonstrasi berbantuan software geogebra dan variabel terikat yaitu pemahaman matematika siswa. Populasi (Sugiyono, 2010 : 61) adalah wilayah generalisasi yang terdiri atas objek atau subjek yang memiliki kualitas dan karakteristik tertentu. Populasi penelitian ini adalah semua kelas X MAN 2 kota Cirebon pada semester ganjil tahun ajaran 2015/2016 sebanyak 40 siswa. Sedangkan sampel penelitian (Sugiyono, 2007 : 56) adalah sebagian dari jumlah populasi yang memiliki karakteristiknya. Pengambilan sampel dilakukan dengan menggunakan teknik cluster random sampling, yaitu pengambilan sampel yang memperhatikan sub-sub populasi yang kemudian sub-sub populasi dipilih secara acak sehingga diperoleh kelas XA jumlah sampel sebanyak 40 siswa.

Tabel 1

Populasi Kelas X MAN 2 Cirebon TA 2015/2016 ganjil

\begin{tabular}{cc}
\hline Kelas & Jumlah Siswa \\
\hline XA & 40 \\
XB & 41 \\
XC & 41 \\
XD & 40 \\
XE & 42 \\
XF & 40 \\
XG & 40 \\
XH & 41 \\
XI & 41 \\
\hline
\end{tabular}

Instrumen yang digunakan untuk mengukur respons siswa terhadap metode pembelajaran adalah angket. Dan instrumen untuk mengukur pemahaman matematika siswa digunakan tes matematika bentuk essay. Metode penelitian yang digunakan dalam penelitian ini adalah studi eksperimen yang berarti secara 
nyata untuk melihat sebab akibat terhadap penerapan perlakuan tertentu. Sedangkan desain penelitian yang digunakan adalah One Short Chase Study dengan diagram sebagai berikut: $X \rightarrow 0$

Keterangan:

X : Perlakuan (Variabel bebas)

$\mathrm{O}$ : Hasil atau nilai (Variabel terkait)

$\rightarrow \quad$ : pengaruh

Teknik analisis data yang digunakan adalah regresi sederhana untuk mencari besaran pengaruh antara metode pembelajaran demonstrasi berbantuan geogebra terhadap pemahaman matematika siswa. Dimana sebelum dilakukannya analisis data terlebih dahulu data dianalisis menggunakan uji moralitas dan homogenitas data sebagai uji prasyarat penelitian untuk membuktikan data berasal dari distribusi normal dan homogen yang selanjutnya dilakukan uji regresi.

Tabel 2

\begin{tabular}{ll}
\multicolumn{2}{c}{ Kriteria persentase angket } \\
\hline Skor $(\%)$ & Kriteria \\
\hline $0-20$ & Sangat Lemah \\
$21-40$ & Lemah \\
\hline
\end{tabular}

\begin{tabular}{ll}
\hline $41-60$ & Cukup \\
$61-80$ & Kuat \\
$81-100$ & Sangat Kuat \\
\hline
\end{tabular}

(Riduwan, 2006 : 41)

Hipotesis penelitian ini adalah:

$\mathrm{H}_{\mathrm{o}} \quad$ : tidak terdapat pengaruh penggunaan metode pembelajaran demonstrasi berbantuan software geogebra terhadap pemahaman matematika siswa

$\mathrm{H}_{\mathrm{a}} \quad$ : terdapat pengaruh penggunaan metode pembelajaran demonstrasi berbantuan software geogebra terhadap pemahaman matematika siswa

\section{HASIL DAN PEMBAHASAN} Hasil Penelitian

Dalam penelitian ini menggunakan sampel kelas X SMPN $X$ sebanyak 50 siswa. Penelitian ini menerapkan metode pembelajaran demonstrasi berbantuan software geogebra terhadap pemahaman matematika siswa pada pokok bahasan transformasi geometri. Sehingga instrumen yang digunakan berupa tes essay dan angket respons siswa.

Tabel 3

Deskripsi data penelitian

\section{Descriptive Statistics}

\begin{tabular}{lrrr}
\hline & $\begin{array}{c}\text { Metode } \\
\text { Demonstrasi } \\
\text { Berbantuan } \\
\text { Geogebra }\end{array}$ & $\begin{array}{c}\text { Pemahaman } \\
\text { Matematika }\end{array}$ & $\begin{array}{c}\text { Valid N } \\
\text { (listwise) }\end{array}$ \\
\hline $\mathrm{N}$ & 40 & 40 & 40 \\
Range & 18 & 20 & \\
Minimum & 41 & 23 &
\end{tabular}




\begin{tabular}{lrr} 
Maximum & 59 & 43 \\
Mean & 49,97 & 35,03 \\
Std. Deviation & 4,922 & 5,122 \\
Variance & 24,230 & 26,230 \\
\hline
\end{tabular}

Berdasarkan tabel 1 diketahui bahwa dari sampel penelitian sebanyak 40 diperoleh hasil pemahaman matematika siswa dengan skor maksimal 43 diperoleh range sebesar 20, skor minimun sebesar 23, skor maksimum sebesar 43 , skor ratarata sebesar 35,03, nilai standar deviasi atau simpangan baku sebesar 5,122 dan variansi sebesar 26,230. Sedangkan pada variabel metode demonstrasi berbantuan software geogebra diperoleh skor maksimal sebesar 59 dengan range sebesar 18, skor minimum sebesar 41, nilai rata-rata sebesar 49,97, nilai standar deviasi atau simpangan baku sebesar 4,992 dan variansi sebesar 24,230.

Berdasarkan data pada tabel 3 maka dapat disajikan perolehan rata-rata respon siswa dan nilai tes pemahaman matematika siswa dalam bentuk diagram sebagai berikut:

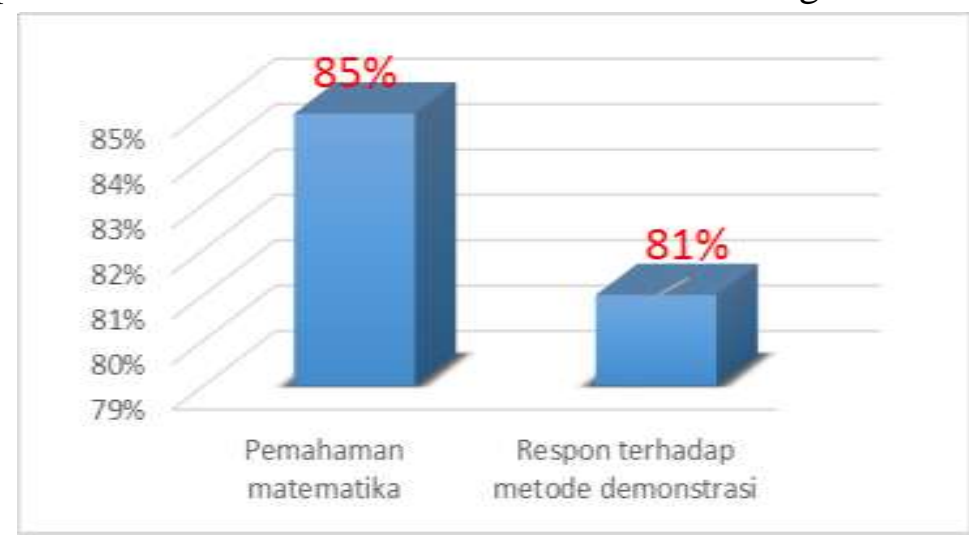

Diagram 1

Hasil rata-rata persentase tes dan angket

Berdasarkan diagram 1 diketahui bahwa rata-rata respons siswa terhadap metode demonstrasi berbantuan software geogebra sebesar $81 \%$ dan nilai rata-rata tes pemahaman matematika siswa pada pokok bahasan transformasi geometri sebesar 85\%. Sehingga dapat dikatakan bahwa adanya hubungan Perolehan nilai pemahaman matematika siswa terhadap metode pembelajaran demonstrasi yang telah diterapkan pada kelas penelitian.

Uji normalitas digunakan untuk mengetahui kenormalan suatu data penelitian. Data dikatakan berdistribusi normal apabila nilai signifikansi lebih dari 0,05. Untuk mengetahui hasil uji moralitas data dapat dilihat di bawah ini.

Tabel 4

Uji normalitas data

Tests of Normality

\begin{tabular}{lllllll} 
Tests of Normality & & \multicolumn{3}{c}{ Shapiro-Wilk } \\
\hline \multicolumn{4}{c}{ Kolmogorov-Smirnov } \\
Statistic & df & Sig. & Statistic & Df & Sig. \\
\hline
\end{tabular}




\begin{tabular}{lllllll}
\hline $\begin{array}{l}\text { Metode Demonstrasi } \\
\text { Berbantuan Geogebra }\end{array}$ &, 132 & 40 &, 075 &, 960 & 40 &, 172 \\
\hline Pemahaman Matematika &, 087 & 40 &, $200^{*}$ &, 965 & 40 &, 253 \\
\hline * This is a lower bound of the true significance & & & & &
\end{tabular}

gificance.

a. Lilliefors Significance Correction

Berdasarkan tabel 4 diketahui hasil uji normalitas data penelitian, diperoleh nilai signifikansi sebesar 0,75 dan 0,200. Karena nilai signifikasi lebih besar dari 0,05 maka disimpulkan bahwa data penelitian berdistribusi normal.

Uji homogenitas digunakan untuk mengetahui bahwa data penelitian berdistribusi homogen atau dengan kata lain adanya penyebaran data secara normal. Keputusan data berdistribusi homogen apabila nilai signifikansi lebih dari atau sama dengan 0,05. Di bawah ini adalah hasil uji homogenitas data penelitian.

Tabel 5

Test of Homogeneity of Variances

Levene Statistic df1 df2 Sig.

$\begin{array}{llll}1,534 & 12 & 22 & , 185\end{array}$

Berdasarkan tabel 5 diketahui hasil uji homogenitas data penelitian, diperoleh nilai signifikansi sebesar 0,185. Karena nilai signifikansi lebih besar dari 0,05 maka disimpulkan bahwa data penelitian berdistribusi homogen.

Uji persamaan regresi digunakan untuk memprediksi sebesar besar pengaruh metode pembelajaran demonstrasi berbantuan software geogebra terhadap pemahaman matematika siswa. Hasil perhitungan uji persamaan regresi adalah:

Tabel 6

Uji persamaan regresi

Coefficients $^{\mathrm{a}}$

\begin{tabular}{|c|c|c|c|c|c|c|}
\hline \multirow[t]{2}{*}{ Model } & & \multicolumn{2}{|c|}{ Unstandardized Coefficients } & \multirow{2}{*}{$\begin{array}{c}\text { Standardized } \\
\text { Coefficients } \\
\text { Beta }\end{array}$} & \multirow[t]{2}{*}{$\mathrm{t}$} & \multirow[t]{2}{*}{ Sig. } \\
\hline & & B & Std. Error & & & \\
\hline & (Constant) & 4,773 & 6,893 & & ,693 & ,493 \\
\hline 1 & $\begin{array}{l}\text { Metode Demonstrasi } \\
\text { Berbantuan Geogebra }\end{array}$ & 605 &, 137 &, 582 & 4,410 & 000 \\
\hline
\end{tabular}

a. Dependent Variable: Pemahaman Matematika

Berdasarkan tabel 6 diketahui nila signifikansi kurang dari 0,000. Dengan demikian dapat disimpulkan bahwa persamaan regresi kedua variabel sebagai berikut:

$\mathrm{Y}=4,773+0,605 \mathrm{X}$

Keterangan

$\mathrm{X} \quad=$ metode pembelajaran demonstrasi berbantuan software geogebra

$\mathrm{Y} \quad=$ pemahaman matematika siswa pada pokok bahasan transformasi geometri

Konstanta sebesar 4,773 artinya jika penggunaan metode pembelajaran demonstrasi berbantuan software geogebra nilainya 0 maka Pemahaman matematika siswa nilainya sebesar 0,605 . Koefisien regresi bernilai positif menyatakan adanya 
pengaruh yang positif antara metode pembelajaran demonstrasi berbantuan software geogebra terhadap pemahaman matematika siswa.

Tabel 7

Uji koefisien determinasi

\begin{tabular}{|c|c|c|c|c|}
\hline \multicolumn{5}{|c|}{ Model Summary $^{b}$} \\
\hline Model & $\mathrm{R}$ & R Square & $\begin{array}{l}\text { Adjusted R } \\
\text { Square }\end{array}$ & $\begin{array}{l}\text { Std. Error of the } \\
\text { Estimate }\end{array}$ \\
\hline 1 &, $582^{\mathrm{a}}$ & ,338 & 321 & 4,220 \\
\hline $\begin{array}{l}\text { a. Pred } \\
\text { b. Dep }\end{array}$ & $\begin{array}{l}\text { onstant } \\
\text { ariable: }\end{array}$ & $\begin{array}{l}\text { Metode Den } \\
\text { emahaman N }\end{array}$ & $\begin{array}{l}\text { trasi Berbantua } \\
\text { matika }\end{array}$ & ogebra \\
\hline
\end{tabular}

Koefisien determinasi digunakan untuk mengetahui seberapa besar kontribusi metode pembelajaran demonstrasi berbantuan software geogebra terhadap pemahaman matematika siswa. Berdasarkan output uji koefisien determinasi diperoleh nilai adjusted $R$ Square sebesar 0,321 atau 32,1\%. Hal ini menunjukkan bahwa persentase kontribusi metode pembelajaran demonstrasi berbantuan software geogebra terhadap pemahaman matematika siswa sebesar $32,1 \%$ dan siswanya $68,9 \%$ dipengaruhi oleh variabel lain. Sedangkan koefisien korelasi (R) sebesar 0,582 berarti terdapat korelasi metode pembelajaran demonstrasi berbantuan software geogebra terhadap pemahaman matematika siswa dengan kategori kuat.

Uji hipotesis dalam penelitian ini menggunakan uji-t dengan menentukan taraf signifikansi sebesar 0,05. Hasil uji hipotesis penelitian dapat dilihat melalui tabel berikut.

Tabel 8

Uji hipotesis penelitian

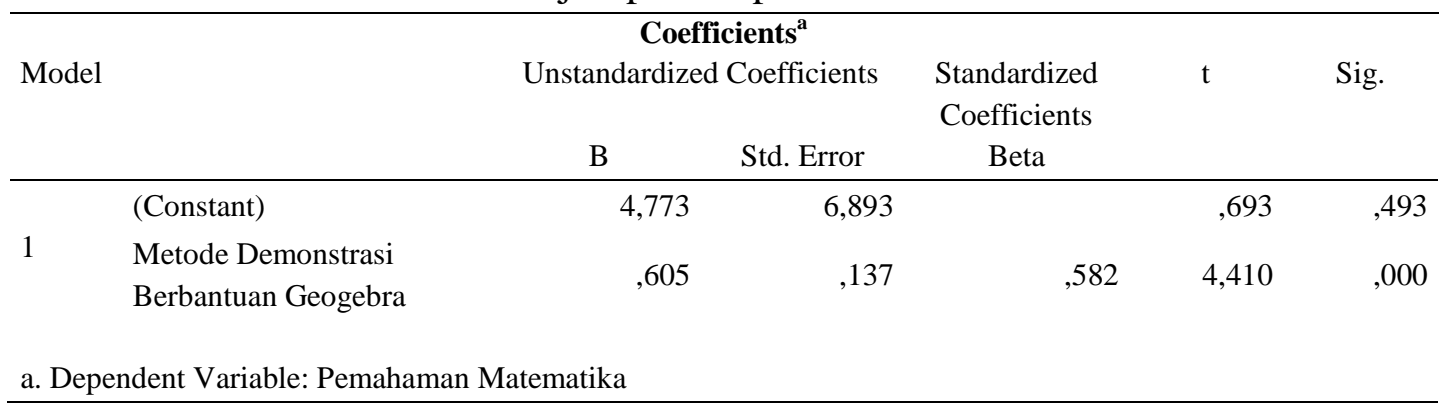

Berdasarkan hasil tabel 8 diketahui bahwa nilai t-hitung sebesar 4,410 dengan nilai signifikansi sebesar 0,000. Dikarenakan nilai signifikansi kurang dari 0,05 sehingga dapat dikatakan bahwa Ho di tolak yang artinya bahwa adanya pengaruh metode pembelajaran demonstrasi berbantuan software geogebra terhadap pemahaman matematika siswa .

\section{Pembahasan}

Pembelajaran matematika terkadang masih dirasakan jenuh oleh beberapa kalangan siswa. Salah satu faktor yang menyebabkan kejenuhan siswa adalah penyajian pembelajaran yang kurang 
mampu menggambarkan atau memvisualisasikan objek matematika yang abstrak menjadi suatu benda atau peragaan yang dapat dilihat dan diamati langsung oleh siswa. Sehingga siswa dapat memahami konsep dan berbagai pengetahuan lainnya yang sedang dipelajari di sekolah.

Penelitian ini memberikan alternatif pembelajaran menggunakan metode demonstrasi berbantuan software geogebra yang diharapkan mampu memberikan pemahaman yang lebih terkait pokok bahasan transformasi geometri. Metode pembelajaran demonstrasi ini menggunakan bantuan software geogebra untuk membuat dan memvisualisasi konstruksi bangun ruang transformasi geometri. Sehingga siswa dapat mengamati beberapa unsur dan sifat dari transformasi geometri tersebut. Lebih lanjut lagi diharapkan siswa dapat memahami lebih luas dengan cara dapat membedakan dan memahami karakteristik dari transformasi geometri.

Dari sampel yang digunakan dalam penelitian ini sebanyak 40 siswa. Instrumen yang disebarkan kepada siswa merupakan tes matematika berupa essay dan angket untuk mengetahui respon siswa terhadap metode pembelajaran demonstrasi berbantuan software geogebra.

Berdasarkan hasil deskripsi data pada tabel 1 di atas, diketahui nilai rata-rata pemahaman matematika siswa pada pokok bahasan setelah penggunaan metode pembelajaran demonstrasi berbantuan software geogebra sebesar 35 dengan nilai minimum dan maksimum sebesar 23 dan 59. Hal ini menunjukkan arti bahwa pemahaman matematika siswa cenderung meningkat.

Ditinjau dari aspek yang diukur dalam pemahaman matematika siswa diketahui nilai maksimum sebesar 43 dari total keseluruhan 50. Hal ini menunjukkan bahwa siswa mampu menginterpretasikan kembali konsep yang telah dipelajarinya. Dengan kata lain siswa telah dapat memahami materi pelajaran matematika pada pokok bahasan transformasi geometri. Sedangkan berdasarkan deskripsi hasil respons siswa terhadap metode pembelajaran demonstrasi berbantuan software geogebra diketahui skor ratarata sebesar 49,94 dengan skor maksimal sebesar 41 dan skor minimal sebesar 59. Hal ini memberikan arti bahwa siswa memiliki rasa senang dan menerima dengan baik metode yang diterapkan yaitu metode demonstrasi berbantuan software geogebra. Skor maksimal 59 yang menyatakan terdapat siswa yang sangat antusias dan memiliki minat belajar matematika yang tinggi dengan diterapkannya metode demonstrasi ini. Hasil uji t-hitung sebesar 4,410 dengan signifikansi sebesar 0,000 . Sehingga dalam hal ini Ho ditolak yang artinya terdapat pengaruh penggunaan metode demonstrasi berbantuan software geogebra terhadap pemahaman matematika 
siswa. Hal ini juga diperkuat dengan Perolehan koefisien determinasi sebesar 0,582 yang menunjukkan bahwa pemahaman matematika siswa dalam penelitian ini ditentukan oleh metode pembelajaran demonstrasi berbantuan software geogebra sebesar $32,1 \%$.

Berdasarkan uraian di atas maka disimpulkan bahwa terdapat pengaruh penggunaan metode pembelajaran demonstrasi berbantuan software geogebra terhadap pemahaman matematika siswa yang ditunjukkan oleh rata-rata nilai tes pemahaman matematika pokok bahasan transformasi geometri sebesar $85 \%$, persentase respons siswa terhadap metode pembelajaran demonstrasi berbantuan software geogebra sebesar $81 \%$ serta uji regresi sederhana yang menyatakan signifikansi yang kuat.

\section{E. KESIMPULAN DAN SARAN Kesimpulan}

1. Diperoleh rata-rata nilai tes pemahaman matematika siswa pada pokok bahasan transformasi geometri sebesar 35,03 atau setara dengan $85 \%$.

2. Persentase rata-rata respons siswa terhadap model pembelajaran demonstrasi berbantuan software geogebra sebesar $81 \%$.

3. Terdapat pengaruh penggunaan model pembelajaran demonstrasi berbantuan software geogebra terhadap pemahaman matematika siswa

\section{Saran}

1. Bagi para pendidik atau guru, metode pembelajaran demonstrasi dapat dijadikan alternatif metode pembelajaran untuk meningkatkan pemahaman matematika siswa sehingga diharapkan hasil belajar matematika ikut meningkat

2. Bagi para peneliti selanjutnya:

a. Memperhatikan penyajian dan keterampilan penggunaan software geogebra agar lebih kreatif dan interaktif bagi siwa sehingga objek matematika dapat diamati dengan baik

b. Memperhatikan narasi lisan saat mendemonstrasikan materi bersamaan dengan menggunakan software geogebra agar mudah dipahami oleh siswa

\section{DAFTAR PUSTAKA}

Arikunto, Suharsimi. 2009. Dasar-dasar Evaluasi Pendidikan. Jakarta: Bumi Aksara

Hamalik, Oemar. 2009. Psikologi Belajar dan Mengajar. Bandung: Sinar Baru Algesindo

Hamdani. 2011. Belajar dan Pembelajaran. Bandung: Alfa Beta

Permana , Irvan. 2011. Pengaruh Metode Pembelajaran Demonstrasi pada Pokok Bahasan Bilangan Bulat terhadap Prestasi Belajar Siswa di SMPN 1 Sumber Kabupaten Majalengka.

Priyatno, Dwi. 2011. Belajar Cepat Olah Data Statistik dengan SPSS. Yogyakarta: Andi

Riduwan. 2006. Belajar Mudah Penelitian untuk Guru karyawan dan Peneliti Pemula. Bandung: Alfabeta 
Ruseffendi, E.T. 2006. Pengantar Kepada Membantu Guru Mengembangkan Kompetisinya dalam Pengajaran Matematika untuk Meningkatkan CBSA. Bandung: Tarsito

Rusman. 2011. Model-model Pembelajaran, Jakarta: Rajawali Pers

Sanjaya, Wina. 2011. Strategi Pembelajaran Berorientasi Standar Proses Pendidikan. Jakarta: Kencana

Slameto. 2010. Belajar dan Faktor-faktor yang Mempengaruhinya. Jakarta: Rineka Cipta

Sugiyono. 2007. Metode Penelitian Pendidikan. Bandung: Alfabeta

Sumarno, Utari. 2010. Berpikir dan Disposisi Matematika: Apa, Mengapa dan Bagaimana dikembangkan pada peserta didik. Online 
